anticoagulants are not free from the risk of profuse haematuria. ${ }^{12}$

It is difficult to imagine cryoprostatectomy becoming more popular in its present form, and indeed it has been abandoned in some centres after poor (unpublished) results. Its success must always depend on the size, shape, and vascularity of the prostate gland and on the need to freeze just enough tissue for just long enough without damaging the surrounding organs and sphincter areas.

Anaesthesia has reached a sufficiently high standard for few patients to be so ill that they cannot withstand the short anaesthetic necessary for a palliative transurethral resection. In these the operation need provide only a "channel" sufficient to allow adequate urination for what must inevitably be a limited life expectancy. Even the presence of a cardiac pacemaker need not be a contraindication to resection. ${ }^{15}$

An interesting consequence of cryosurgery is the "immunocryothermic response" that has been observed in some patients with metastatic carcinoma of the prostate. ${ }^{16}$ Prostatic autoantibodies have been detected, and their production is boosted by a second freeze at an interval of 30 days. The production of prostatic tumour-specific antibodies might lead to a further line of attack on these tumours.

1 Cooper, I. S., New England Fournal of Medicine, 1963, 268, 743.

Gonder, M. J., Soanes, W. A., and Smith, V., Annals of the New York Academy of Sciences, 1965, 125, 716

Ehrlich, R. M., Tannenbaum, M., Roberts, M., and Lattimer, J. K., Fournal of Urology, 1969, 101, 890.

Soanes, W. A., Gonder, M. J., Albin, R. J., Maser, M. D., and Jagodzinski, R. V., Fournal of Cryosurgery, 1969, 2, 23.

Ortved, W. E., O'Ǩelly, F. M., Todd, I. A. D., Maxwell, J. B., and Sutton, M. R., British fournal of Urology, 1967, 39, 577.

- Dow, J. A., fournal of Urology, 1968, 100, 66.

Dowd, J. B., Flint, L. D., Zinman, L. N., and Tripathi, V. N. P., Surgical Clinic of North America, 1968, 48, 627.

- Marshall, A., Procecdings of the Royal Society of Medicine, 1968, 61, 1139.

- Jordan, W. P., Walker, D., Miller, G. H., and Drylie, D. M., Fournal of Cryosurgery, 1968, 1, 130.

10 Hansen, R. I., Lund, F., and Backer, O. G., Urologia Internationalis, 1969, 24, 160.

11 Sesia, G., Ferrando, V., and Laudi, M., International Surgery, 1970, 53, 82.

12 Green, N. A., British fournal of Urology, 1970, 42, 10.

1s Gill, W., Fraser, Sir J., Long, W., and Lee, P., Surgery, Gynecology and Obstetrics, 1970, 131, 877.

Walker, D., Jordan, W. P., jun., Drylie, D. M., and Miller, G. H., fournal of Urology, 1968, 100, 188

15 Fein, R. L., fournal of Urology, 1967, 97, 137.

16 Albiin, R. J., Soanes, W. A., and Gonder, M. J., International Surgery, $1969,52,8$.

\section{Congenital Dislocation of the Hip}

Since pioneer work in Italy and Sweden, and in Britain notably by T. G. Barlow, ${ }^{1}$ congenital dislocation of the hip is being diagnosed in the first fortnight of life. The frequency of neonatal diagnosis is about 4 per 1,000 live births-four times as high as the frequency of late diagnosis cases in Sweden and Britain. Recently it has become clear that the discrepancy is due to the fact that of every four cases of dislocation of the hip picked up in the neonatal period three would recover spontaneously. In Edinburgh, for example, where neonatal diagnosis has been attempted for a decade, the incidence of late diagnosis patients has now dropped to little more than 1 in $10,000 .^{2}$ Since neonatal treatment is so simple compared to later treatment the overtreatment of neonatal patients is well worthwhile.

Much of the work on causation is based on studies of late diagnosis cases, such as that summarized by $C$. $O$. Carter and J. A. Wilkinson. ${ }^{3}$ They noted the evidence for two environmental factors and two genetic factors-generalized joint laxity (probably single gene determined) and acetabular dysplasia (likely to be polygenic). One environmental factor was prenatal-the intrauterine malposition of flexed hips and extended knees, often but not necessarily associated with breech presentation; the other was postnatal-the tendency to swaddle the child with hips adducted and extended.

What, however, is the nature of the cases which correct themselves? A recent extensive family study from Edinburgh by Ruth Wynne-Davies ${ }^{24}$ has thrown some ligh: on this. There was about twice as high a proportion of boys among the neonatal patients as among those diagnosed late. The family study, however, indicated an essential similarity of the two conditions: of the sibs of the neonatal cases, mostly born since 1960, 13\% had a diagnosis (mostly neonatal) of hip dislocation. These proportions of first degree relatives affected are similar to those in earlier studies in Birmingham ${ }^{5}$ and London ${ }^{6}$ when allowance is made for the increased frequency of neonatal diagnosis. There were, however, differences between the two groups in the relative contributions of the two genetic factors. Acetabular dysplasia was clearly seen, as measured on radiographs, in the parents of the late diagnosis cases, while in the parents of neonatal cases the signs of acetabular abnormality were less marked and not significantly different from the control series. Joint laxity, however, was more often found in both patients with the neonatal form and their first degree relatives.

Wynne-Davies suggests, therefore, that familial joint laxity plays a relatively greater part in the cases of congenital dislocation of the hip which recover spontaneously, and that acetabular dysplasia is relatively more important in the cases which, before the introduction of neonatal treatment, used to persist and present as late diagnosis cases. This would fit with her observation that the female preponderance is less marked among the neonatal patients, especially as persistent joint laxity plays a bigger part in causing hip dislocation in boys than in girls. ${ }^{7}$ It would also fit with the observation ${ }^{8}$ that among late diagnosis patients those with acetabular dysplasia respond less well to conservative treatment.

As a practical problem in paediatrics congenital dislocation of the hip is largely solved where practitioners skilled in neonatal examination and treatment are to hand. There is no way yet to distinguish the majority of neonatal patients who will recover spontaneously, and so all should be treated. Where resources for neonatal examination are limited there is a case for paying special attention to the sibs and offspring of known cases, since their chance of having the disorder is some 25 times the random risk. It should, however, be borne in mind that where a substantial degree of acetabular dysplasia is contributing to the dislocation (and this cannot be measured neonatally) this dysplasia is likely to persist and may cause early osteoarthritis. 910 Long-term follow-up of neonatal cases to look for this is needed. It may even be the case that prophylactic surgery may be desirable to improve the cover of the femoral head by the roof of the acetabulum if there are instances where considerable acetabular dysplasia becomes apparent after neonatal treatment.

1 Barlow, T. G., fournal of Bone and foint Surgery, 1962, 44B, 292.

2 Wynne-Davies, R., fournal of Medical Genetics, 1970, 7, 315.

3 Carter, C. O., and Wilkinson, J. A., Clinical Orthopedics, 1964a, 33, 119.

Wynne-Davies, R., fournal of Bone and foint Surgery, 1970, 52B, 704. Record, R. G., and Edwards, J. H., British fournal of Social and Preventive Medicine, 1958, 12, 8.

6 Carter, C. O., in Counselling and Progress in Medical Genetics, ed. A. G. Motulsky. New York, Hoeber. In press.

7 Carter, C. O., and Wilkinson, J. A., fournal of Bone and foint Surgery, $1964,46 \mathrm{~B}, 40$

8 Wilkinson, J. A., and Carter, C. O., fournal of Bone and foint Surgery, $1960,42 \mathrm{~B}, 669$.

9 Wiberg, G., fournal of Bone and foint Surgery, 1953, 35A, 65. Lloyd-Roberts, G. C., fournal of Bone and foint Surgery, 1955, 37B,
8. 